\title{
COLLECTIVE INTENTIONALITY IN ORGANIZATIONS: A META-ETHNOGRAPHY OF IDENTITY AND STRATEGIZING
}

\section{Christopher W. J. Steele and Brayden G King}

\begin{abstract}
Sociologists often treat groups and organizations as if they had collective intentionality - that is, a collective impetus for action that exists semiindependently of the members of the group. At present, however, we lack a sound understanding of how collective intentionality is achieved or maintained. Furthermore, although organizations provide a well-defined and distinctive setting for an empirical and theoretical investigation of collective intentionality, organizational intentionality in its own right has received little attention. In this chapter, we seek to address the relationship between collective intentionality, organizational identity, and organizational decisionmaking, using the potentially powerful method of meta-ethnography: the comparison, contrast, and synthesis of multiple ethnographies.
\end{abstract}

What does it mean to say that a group or organization has intentions? Is collective intentionality somehow distinct from the shared intentions of individuals? And, if it is, how do collective intentions come to exist and to be

Advances in Group Processes, Volume 28, 59-95

Copyright (C) 2011 by Emerald Group Publishing Limited

All rights of reproduction in any form reserved

ISSN: 0882-6145/doi:10.1108/S0882-6145 (2011)0000028006 
enacted? Such questions are central to theories about group behavior and organization. Underlying many sociological theories is the assumption that groups, in a very real sense, deliberate, have goals and beliefs and take action and that the actions, purposes, and beliefs of the group are semi-independent of its members. It follows that if the group was disaggregated into its constituent members, they would individually be unlikely to pursue the same purposes or take the same actions. Accordingly, such theories implicitly suggest that collective action and purpose reflect the collective intentionality of the group. We assume that groups develop collective orientations that are more than just the aggregation of the individual mental states or intentions of their members and that this orientation or "group mind" guides and provides coherence to the group's behaviors (Weick \& Roberts, 1993).

Such an assumption is also reflected in common parlance. We speak of organizations or communities as if they had intentionality: of actions taken on behalf of the family honor or for the good of the church; the will of the state; the responsibilities of the corporation; or even of the actions, the good, and the future of humankind. Although some dismiss such talk as merely misleading metaphor, others believe that organizations and nations, in a very real sense, have moral obligations and responsibilities. In their everyday lives, many if not most people act as if organizations have desires, as if communities have loyalties, and as if nations have self-interests. Considering the motives and beliefs of organizations or other collectives helps us to make sense of group behavior and make reasonable predictions about future behavior. Indeed, this form of interpretation "allows us to discern real patterns of social behavior, patterns that are missed if one attempts to explain the social world by appealing only to individual intentional states" (Tollefsen, 2002, p. 43; see also Dennett, 1987; Pettit, 2003).

The purpose of this chapter is to examine the processes that enable collective intentionality in organizations, as a specific and particularly significant social form. We maintain that the intentionality of organizations is fixed by their identities as special kinds of social actors (Coleman, 1982; King, Felin, \& Whetten 2010). This identity provides the organization's "internal self-view" around which its members deliberate and make key decisions. Although organizational actions are never entirely predictable, the self-view of organizations gives coherence and meaning to decisions and to the organization's strategic direction - both for members and for its audiences. At present, however, we still lack an explanation for how identity channels and directs individuals' behaviors to produce coherence in group decision-making and how this is related to audiences' expectations. The purpose of the chapter, then, is to illuminate the process through which 
an organizational identity is generated through ongoing decision-making and commitments and thereby to develop an understanding of how collective intentionality emerges through the interplay of organizational identity and strategic decision-making.

To do this, we draw upon the rarely used but potentially powerful method of meta-ethnography to bring together and synthesize existing, rich, ethnographic data on organizational identity and decision-making. Using carefully defined inclusion and exclusion criteria, we carried out extensive searches of the ethnographic literature and identified six ethnographic studies dealing with organizational identity and strategic decision-making. We made a detailed analysis of each, focusing on commonalities and differences, and this rich, qualitative data allowed us to build a detailed impression of the development of collective intentionality within organizations. On the basis of the meta-ethnographic findings, we propose a process model, which we believe captures the broad conceptual relationships highlighted by these data. We offer this process model, describing the relation between organizational identity and strategic decision-making, as an illustrative framework for further consideration of organizational intentionality. We believe this model of the principles and cyclical nature of the formation, maintenance, and transformation of collective intentionality within organizations offers a useful rationale to guide the design of future research in this area.

\section{THEORETICAL BACKGROUND}

\section{Sociology and Collective Intentionality}

Sociologists, perhaps more than most scholars, have embraced the idea that collectives have emergent properties, independent of the individuals who constitute the group. This idea was apparent in the work of the discipline's founding figures, including Durkheim's (1965) work on the use of rituals as a source of collective emotion, Weber's (1947) theory of bureaucracy, and Simmel's (1971) theory of social forms as distinct collective units and has since been taken forward in various directions. Despite sociologists' longstanding concern with the development of groups and organizations as distinct social units, however, collective intentionality has remained an implicit rather than explicit concern - with a few notable exceptions.

James Coleman (1982), for instance, focused not on the composition or re-creation of collective actors, through rituals, rules, or other means, but on the nature of organizations as legal and practical persons. He emphasized 
the point that organizations are treated as persons all the time: that salespersons, or waitresses, for example, may often feel some sense of obligation (or some indifference to or resentment of) the organization for which they work (Coleman, 1982). Also, he reminds us, organizations have rights and responsibilities before the law. And if organizations have rights and responsibilities, may espouse certain values, elicit a sense of obligations, and fund preferred political candidates, it would seem reasonable to postulate that they also have independent motivations.

Whereas Coleman showed how collective actors may share the features of individuals, Bruno Latour (2005) sought to break down the distinction between the individual and the collective more completely. Latour argues that individual intentionality is primarily derived from the influences, urges, and restrictions of the many other actors surrounding and defining that individual. The individual, rather than being something a priori, is largely an effect of its relationships with both human and nonhuman actors - it is the point at which a great variety of other actors meet and through which they negotiate some action. The collective is similarly and equally an individual actor. For Latour, the organization is an actor, in the same sense as the CEO. ${ }^{1}$

Such examples illustrate the strong theme in much sociological theorizing that organizations and collectives are distinctive entities with emergent properties and institutionalized structures that cannot be reduced to the individuals that constitute them (Merton, 1940; Meyer \& Rowan, 1977; Selznick, 1957). More importantly, sociological theories of collectives - even when they challenge the very concept of individuality and individual intentionality - postulate that individual behavior is oriented to the existence and behavior of collectives or groups. They thus highlight an important role for the identity of collectives (whether these identities are unitary or contested). Their notions of collective intentionality largely rely on the analytic and everyday perception of a collective entity as something with its own features and nature, and in the case of Coleman, with its own individuality and personality.

Any investigation into collective intentionality must of course define its scope rather carefully. In this chapter, we focus on formal organizations because the organization is not only a prevalent and significant type of collective in modern life (see also Chandler, 1993; Perrow, 1986; Weber, 1947) - one which acts as the site of many modern rites and rituals (Beyer \& Trice, 1987; Meyer \& Rowan, 1977) - but also one that is endowed with legal responsibility and agency. The organization is an actor that is, every day, practically, legally, and linguistically granted intentionality and agency (King et al., 2010). 


\section{Organizational Theory and Organizational Identity}

If we are to believe that organizations have a special status as intentional actors, what is the source of this intentionality? Past scholarship has focused on two plausible yet incomplete explanations. ${ }^{2}$ The first is that intentionality is based in the structure and design of the organization, as Weber suggested when he theorized about the bureaucratic form. In these approaches, incentive systems, routines, roles, and rules are understood to define or shape how members should, and do, carry out their duties (e.g., Dosi, Faillo, \& Marengo, 2008; Floyd \& Wooldridge, 1992; Prendergast, 1999; Tollefsen, 2002). Once a structure is properly specified, individuals become substitutable, and the organization and its characteristics can survive in the face of frequent turnover through the continued enactment of the established structure. Incentive systems, routines, roles, and rules, in this sense, build intentionality through the alignment of organizations' structures and goals. To give an explicit example, Tollefsen (2002, p. 401) embraces this explanation when she argues that the "rational point of view" of the organization is facilitated by a particular structure:

\footnotetext{
The distribution of labor within an organization reduces the responsibility of individuals, and the formalization of rules, authority structures, and organizational roles constrains choices and makes available to the agent the information necessary to perform in her role. By providing integrated subgoals, stable expectations, required information, necessary facilities, routine performance programs and in general a set of constraints within which required decisions can be made, organizations direct individual participants. It is the formalization of rule and role and the specificity of goals and subgoals that creates an environment in which agents can act individually and jointly to achieve organizational goals. The structure of the organization provides a way of synthesizing the disparate perspectives of individuals into a unified perspective from which goals and subgoals can be set and achieved.
}

Unfortunately, although managers may design organizations to do exactly this - that is, to coordinate individuals' behavior to automatically produce a unified perspective and reliable outputs - organizations are notoriously difficult to completely rationalize, leaving room for plenty of slippage and decoupling of structure and behavior (Meyer \& Rowan, 1977). Organizations and their practices become naturalized and taken-for-granted as members bring their own interests to bear on the organization, implicitly shaping its character and structure over time, in ways that may well not reflect the original intentions behind the organization's design (Selznick, 1957). Furthermore, the elements of this design are inevitably incomplete. Incentives are often insufficient or may send, at times, conflicting messages to participants. 
Similarly, routines and rules cannot possibly specify all the conditions under which individuals must make decisions (Duguid, 2005; Lynch, 1992; Tsoukas, 2005), and when they are crafted to be relatively more comprehensive, they may not provide the sort of discretion needed to make the most critical decisions that guide organizational growth and problem solving (Felin \& Foss, 2006). Last, but not least, individuals, despite or because of their adherence to certain roles, often fail to abide by the letter of particular rules (Orr, 1996; Wenger, 1998). In sum, organizations may very fruitfully be conceptualized as natural systems (Scott \& Davis, 2007), and, as such, they cannot be so completely rationalized as to wipe out differences across individual members or to ensure uniform decision-making.

The second explanation of intentionality posits that individuals come to identify so completely with the organization (Ashforth, Harrison, \& Corley, 2008; Ashforth \& Mael, 1989), or become so socialized into the practices, values, and beliefs embedded in organizational culture (Scott, 2001; Weick, 2001), that they no longer need to be told what do (see Hatch \& Schultz, 2002; Scott, 2001; Weick, 2001). They work for the interest of the organization because they are socialized to believe implicitly, or explicitly, in its goals and purposes - and, inasmuch as individuals come to share the same feelings, commitment, and beliefs, there is no need for managers or others to direct employees: organizational members simply perform their duties. ${ }^{3}$ This view of organizations is characterized by work on organizational culture, which emphasizes how individuals are selected into and socialized to fit a particular organization's culture (Chatman, 1991).

Unfortunately, this explanation is burdened with an over-socialized depiction of individual behavior (Granovetter, 1985; Wrong, 1961) that some have claimed reduces individuals to "cultural dopes" (see de Certeau, 1984; Garfinkel, 1961; Granovetter, 1985). And while identification may be desirable for many reasons, organizations cannot rely solely on the emergence of shared beliefs and strong commitment to induce behavior. ${ }^{5}$ Moreover, there is much evidence to suggest that organizations exhibit internal identity heterogeneity, leading to fragmentation in member beliefs and competition for jurisdictional control (e.g., Bechky, 2003; Brown, 2006; Brown \& Humphreys, 2006). One need not identify wholly with the organization to be a competent member. We assume, instead, that individuals often have very different beliefs about what is right for the organization, that they are imperfectly socialized, and that their levels of identification with the organization vary substantially.

Given the difficulties with these two explanations, how can we account for the intentionality of organizations? How do organizations influence their 
members sufficiently to produce coherent collective outcomes? The literature on organizational identity suggests several directions of inquiry. This literature began under the auspices of Philip Selznick (1957), who argued that organizations will develop a distinctive character over time, as various constituencies within the organization seek to impose on the organization their own values and interests. This character, Selznick argued, becomes naturalized, such that actions or procedures are justified with reference to organizational character, and others become taboo, or at the least, difficult to institute and enforce. Selznick contended that organizations develop stable and enduring cores, entailing certain understood values, ends, and means without adopting a naïvely over-socialized conception of individuals (i.e., he suggests that individuals pursue their own interests, but become acclimated to the organizational character over time, learning how to get what they want by accessing and engaging with this character).

Albert and Whetten (1985) connected this notion of organizational character explicitly to organizational identity, arguing that organizational identity consisted of the features of the organization that were central, enduring, and distinctive. These features not only define the organization's domain - for example, what kind of organization are we? - but also guide key organizational decision-making processes (see Whetten, 2006). As the organization is a key actor in most transactions or discussions of weight within its boundaries, individuals in an organization learn how to make decisions and promote their objectives and agendas with reference to its needs and purposes (King et al., 2010). That is, the organization's identity does not simply replace that of its members; rather, the organization's identity, as a shared understanding about what makes this organization distinctive, becomes the primary actor of consideration for consequential decisions, planning, strategizing, and agenda setting. The organization influences members in the same manner as a powerful individual that all members of the organization must work with to succeed. Rather than making the case that organizational continuity requires that its individual members share the same beliefs about what is right or valuable, the concept of organizational identity implies that individuals only share some degree of common understanding of what they think the organization sees as right or valuable. Organizational identity, in this sense, creates a strong context that heavily anchors group deliberation, shapes the framing of individuals' expression of their own interests, and provides the framework for goal setting and strategic decision-making. ${ }^{6}$

Nevertheless, although the notion of collective intentionality is implicitly central to the literature on organizational identity - whether in the form of 
group consciousness or the organizational actor - we as yet lack a good explanation for how organizational identity draws together individual interests and mental states into something we would recognize as collective intentionality. We seek to rectify this, here, through an empirical investigation of the linkage between organizational identity and strategic decision-making, a context in which the formation and maintenance of collective intentionality becomes visible (Whetten, 2006).

Compared to other organizational functions, strategic decision-making is one in which we might expect structure and identification to matter less - being overridden by the demands of the situation - and individual interests or preferences to exert particular influence. Heterogeneous personal beliefs are likely to influence how individuals approach strategy, and strategic decisionmaking may provide an opportunity for them to change the course and potentially alter the character of the organization. Despite this opportunity for individual intentionality to trump the collective, strategic decision-making can be a key context in which organizational identity becomes especially visible. As Whetten (2006, pp. 220-221) has argued, organizational identity is "most likely to be invoked in organizational discourse when member agents are grappling with profound, fork-in-the-road, choices - those that have the potential to alter the collective understanding of "who we are as an organization." Such choices seem to be frequently surrounded by intensive episodes of strategic decision-making, the outcome of which could potentially shape the orientation of the whole organization. ${ }^{7}$ Therefore, it seems to us, the strategic decision-making function of organizations provides an appropriate setting for our purpose of examining how organizational intentionality manifests itself. Our contribution in this chapter, thus, is to illuminate the processes by which collective intentionality emerges and operates in strategicdecision making and the role of identity in these processes. We undertake this task through the method of meta-ethnography.

\section{METHODOLOGY AND METHODS}

To develop an understanding of collective intentionality, and the role of organizational identity as it plays out in strategizing, it is important to draw upon rich and relatively thick descriptive accounts of everyday activity - such as those provided by ethnographies. Rather than draw upon a single ethnography, however, we have adopted the rarely used but potentially productive methodology of meta-ethnography. Meta-ethnography is not a single technique but a set of associated techniques that focus on the 
aggregation or synthesis of ethnographic data (Campbell et al., 2003; Doyle, 2003; Hodson, 2004a; Noblit \& Hare, 1988). We are aware of only two meta-ethnographies within the organizational literature (Hodson, 2004a, $2004 \mathrm{~b}$ ), both of which seek to transfer the lessons of quantitative metaanalysis to the realm of the ethnography. We, however, prefer a different approach. Rather than pursue a strategy of intensive data reduction (c.f. Miles \& Huberman, 1994), we have sought to follow a process of reciprocal translation (Campbell et al., 2003; Noblit \& Hare, 1988). As Campbell et al. (2003, p. 673) summarize it,

This entails examining the key concepts in relation to others in the original study, and
across studies, and is analogous to the method of constant comparison used in qualitative
data analysis. The translation of key concepts or interpretive metaphors from one study to
another is idiomatic rather than word-for-word translation, the purpose being to try to
derive concepts that encompass more than one of the studies being synthesized. These
derived or synthesized concepts may not have been explicitly identified in any of the
original empirical studies and resemble second-order constructs in the analysis of primary
qualitative research data (Schutz, 1962) but would in effect be third order constructs.

Through the process of reciprocal translation, we use the individual ethnographies to inform an independent and emergent conceptualization, in the form of a process model, rather than simply aggregating them. This approach is analogous to that described by Noblit and Hare (1988) (see also Campbell et al., 2003) as a "line of argument synthesis," the purpose of which is to "reveal what is hidden in individual studies" and to situate their "similarities and differences [in] a new interpretive context" (Noblit \& Hare, 1988, p. 75).

We began this process by making an inventory of available cases by means of an extensive literature search for ethnographies on strategy formulation and implementation, which explicitly addressed identity. We conducted a total of 24 searches in 4 major databases of social scientific articles and dissertations ${ }^{8}$ as well as searching for "ethnography" in the archives of 9 disciplinary journals. ${ }^{9}$ We then eliminated all returns that were not based on original qualitative research, leaving 87 articles. Next, we established a further set of boundary conditions for inclusion, eliminating all articles that did not involve prolonged participant observation, which did not give sufficient analytic attention to strategy-making or to organizational identity, and which did not present cases with sufficiently rich description. ${ }^{10}$ We then used the ISI Web of Knowledge to identify further papers that cited or were cited by the articles we had identified or the set of literature reviews and highly cited papers that we had constructed separately. Finally, we used the above process of elimination on the identified articles. By the end of this process, we 
had identified six peer-reviewed articles, which we included in the metaethnography.

The first, Karreman and Alvesson (2001), investigates the identity work of members of a Swedish evening newspaper, with particular reference to a meeting about news bills (the selections of stories and story headlines covered in particular issues) - that is, it attends to the ways in which organizational members create and maintain a sense of organizational identity, during an ostensibly functional and strategic meeting. Ybema (2010) examines the competition between two distinctive temporal selfunderstandings, regarding the past, present, and future of a Dutch national newspaper - with reference to an internal debate over whether to maintain or alter its official identity statement. Corley (2004) addresses differences in hierarchical perceptions of, and attitudes regarding, organizational identity and change within a global technology service provider, recently spun-off from its parent company. Barge, Lee, Maddux, Nabring, and Townsend (2008) focus on the ways in which a collective of Native American Colleges and Universities, related stakeholders, and their associated consultants managed a set of awkward dualities (inclusion-exclusion, preservationchange, and centrality-parity) during the development of strategic technology plans. Corley and Gioia (2004) investigate the processes of identity ambiguity and change within a global technology service provider recently spun-off from its parent identity. Finally, Tripsas (2009) examines the relationship between changes in technology and identity within a "digital photography company," making the transition to a "flash memory media company." All address aspects of organizational identity and its relation to strategic decision-making or significant periods of strategizing. Two of these ethnographies appear to address the same case: however, we include them both as they address substantially different aspects of the link between strategy and identity. This may reduce external generalizability; however, our primary concern at this stage is not to generalize directly, but to develop an illustrative framework as a basis for further consideration and to guide further research.

For our analysis, we read each ethnography independently in an attempt to gain a thorough understanding of the case both individually and then through discussion. Outlines of each case were written in the form of "rich translations" (Doyle, 2003; Noblit \& Hare, 1988), which maintained much of the original language and which attempted to draw out and relate the key concepts and metaphors used in the case. These key concepts and metaphors were then used to represent the case diagrammatically, with reference to our analytic concerns. In this manner, we were able both to describe each case 
richly and to examine the ways in which it could be reduced to a conceptual map without losing too much of its power and significance. We then sought to combine the diagrammatic representation of the new ethnography and that of the previous set, so that as we continued, we developed a single diagram that repeatedly assimilated the concepts and relations presented in the ethnographies we studied. We thus included each ethnography in sequence (given earlier) and at each step in this sequence considered how changes in our analysis might alter our understanding and treatment of the previous inclusions. By means of this analytic process, we were able to get a clear picture of how the topics and perspectives of the different ethnographies were related and whether they translated relatively easily to the terms of others or presented contradictions or ambiguities. Furthermore, this diagrammatic approach allowed the results of the synthesis to be presented relatively simply.

As regards the credibility of our interpretations and analysis, two points are significant. First, it is important to note that the subjects of our metaethnography are all peer-reviewed articles, with their own checks on reliability and credibility. Second, some degree of path dependency in our analysis is inevitable due to the sequential nature of inclusion. In this regard, however, it may be useful to conceptualize the analysis as akin to a relatively exhaustive, formalized, and synthetic reading process, such that any biases arising from the inevitable path dependency of analysis would have been ameliorated by the recurrent return to and reinterpretation of previous readings. With these points in mind, our method seems well suited to the meta-analysis of ethnographic evidence and to the development of an illustrative process model.

\section{THE PROCESS MODEL}

\section{Overview}

Our process model is presented in Fig. 1. We also offer a broad interpretation of the six studies, in the light of this model, in Table 1. Within this model, we distinguish between three main domains. We refer to the first domain as organizational style. The concept of organizational style is similar to Weber's notion of ethos, which Swedberg and Agevall describe as a "collective self-representation of a style of life that is characteristic for a group of individuals" (Swedberg \& Agevall, 2005, p. 195; see also McDonnell, 2011). We refer, however, to style to encompass not only the organization's ethos but also the discursive and material activities in which 


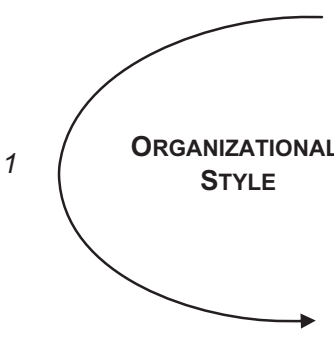

Premises

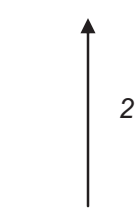

Commitments
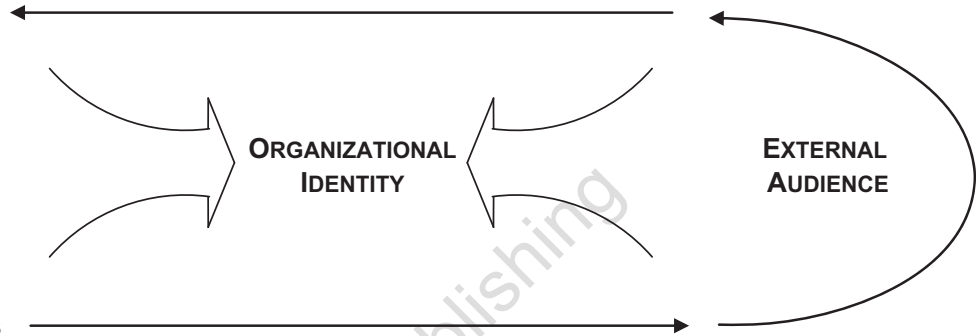

1: 'Strategizing and Decision-Making: Discursive and Conversational Regulation'. Situational Premises guide strategic decision-making, during which members' contributions and suggestions are also regulated, or responded to, in such a manner that key situational premises are generally maintained intact for the future. In the process, both rhetorical and material commitments are made by members on behalf of the organization.

2: 'Reinforcement \& Ambiguation'. As various commitments are made over time, they send signals to both internal and external audiences. These signals can both reinforce or support, or challenge or ambiguate, both situational premises within the organization and external perceptions of the organization. 'Organizational Style' is derived from (and, in its historicity and breadth, forms the context for) the interplay of situational premises and commitments; and the domain of the 'External Audience' is shaped by the processes of reinforcement or ambiguation driven by the commitments to which this style gives rise.

3: 'Situated Interpretation of Perceived External Image and Other Factors'. In turn, 'External Audience' affects 'Organizational Style' through the shaping of situational premises - achieved through the situated interpretation of external actions and statements by organizational members.

As these two broad domains reciprocally mould each other, 'Organizational Identity' emerges as the personality or character of the organization inferred by various internal and external audiences (and thus reflected in situational premises). Various characters may be inferred, but some degree of coherence is likely across audiences' differing notions of organizational identity given that the audiences likely seek to speak with each other, and about 'the same thing'.

Fig. 1. The Formation and Transformation of Collective Intentionality in Organizations: A Process Model. 
Table 1. Broad Interpretations of the Constituent Ethnographies (In Order of inclusion), in the Light of the Concepts of the Synthesis.

\begin{tabular}{|c|c|c|c|}
\hline Synthesis & $\begin{array}{l}\text { A. Karreman and } \\
\text { Alvesson (2001) }\end{array}$ & B. Ybema (2010) & C. Corley (2004) \\
\hline Outline of the case & $\begin{array}{l}\text { This paper investigates } \\
\text { the identity work of } \\
\text { members of a } \\
\text { Swedish evening } \\
\text { newspaper, with } \\
\text { particular reference } \\
\text { to a meeting about } \\
\text { news bills (the } \\
\text { selections of stories } \\
\text { and story headlines } \\
\text { covered in particular } \\
\text { issues) - that is, it } \\
\text { attends to the ways in } \\
\text { which organizational } \\
\text { members create and } \\
\text { maintain a sense of } \\
\text { organizational } \\
\text { identity, during an } \\
\text { ostensibly functional } \\
\text { and strategic meeting }\end{array}$ & $\begin{array}{l}\text { This paper examines } \\
\text { the competition } \\
\text { between two } \\
\text { distinctive temporal } \\
\text { self-understandings, } \\
\text { regarding the past, } \\
\text { present, and future of } \\
\text { a Dutch National } \\
\text { newspaper - with } \\
\text { reference to an } \\
\text { internal debate over } \\
\text { whether to maintain } \\
\text { or alter its official } \\
\text { identity statement }\end{array}$ & $\begin{array}{l}\text { This paper addresses } \\
\text { differences in } \\
\text { hierarchical } \\
\text { perceptions of, and } \\
\text { attitudes regarding, } \\
\text { organizational } \\
\text { identity and change } \\
\text { within a global } \\
\text { technology service } \\
\text { provider, recently } \\
\text { spun-off from its } \\
\text { parent company }\end{array}$ \\
\hline $\begin{array}{l}\text { 1. Organizational } \\
\text { style }\end{array}$ & $\begin{array}{l}\text { The meeting offered } \\
\text { participants a chance } \\
\text { to reaffirm a shared } \\
\text { universe, consisting } \\
\text { of elements such as a } \\
\text { vision of customer } \\
\text { and product, of } \\
\text { apposite } \\
\text { organizational } \\
\text { relations, cognitive } \\
\text { style and rhythm of } \\
\text { work, of the outside } \\
\text { world, and of } \\
\text { mentality (or } \\
\text { attitude) }\end{array}$ & $\begin{array}{l}\text { Members' temporal } \\
\text { understandings } \\
\text { addressed not only } \\
\text { the organization's } \\
\text { past and present but } \\
\text { also its future } \\
\text { direction: These } \\
\text { implied specific } \\
\text { relations to } \\
\text { customers, domains } \\
\text { of appropriate story } \\
\text { coverage, and } \\
\text { apposite mentalities } \\
\text { for members - } \\
\text { whether "light- } \\
\text { hearted", or } \\
\text { "rebellious" (p. 493) }\end{array}$ & $\begin{array}{l}\text { Corley notes differences } \\
\text { across senior } \\
\text { management, middle } \\
\text { management, and } \\
\text { operational } \\
\text { employees in their } \\
\text { perceptions of the } \\
\text { nature and content of } \\
\text { organizational } \\
\text { identity and in their } \\
\text { views of the } \\
\text { appropriate reasons, } \\
\text { means, and process } \\
\text { for implementing } \\
\text { identity change }\end{array}$ \\
\hline $\begin{array}{l}\text { 2. Situational } \\
\text { premises }\end{array}$ & $\begin{array}{l}\text { Participants in the } \\
\text { meeting worked on } \\
\text { the "premise" that } \\
\text { "news bill content }\end{array}$ & $\begin{array}{l}\text { Differing temporal self- } \\
\text { understandings } \\
\text { formed the } \\
\text { background for }\end{array}$ & $\begin{array}{l}\text { Differing assumptions } \\
\text { regarding the nature } \\
\text { of organizational } \\
\text { identity guided }\end{array}$ \\
\hline
\end{tabular}


Table 1. (Continued)

\begin{tabular}{ll} 
Synthesis & $\begin{array}{l}\text { A. Karreman and } \\
\text { Alvesson (2001) }\end{array}$ \\
\hline & sells" (p. 77), which \\
& they largely took for \\
& granted, and which \\
& they reaffirmed when \\
& challenged. This \\
& premise defined and \\
& guided the meeting, \\
& by providing a main \\
"script" (p. 82)
\end{tabular}

3. Strategizing and During the meeting, decision-making: Discursive and conversational regulation

\section{Commitments}

5. Reinforcement The outputs of this and ambiguation or committed to meeting and to a common organizational universe participants engaged in the "selfregulation of a shared identity" (p. 83). They ensured the continued acceptance of the meetings' premise, and its associated script, through the silencing or dismissing of doubts, and through open reaffirmation
B. Ybema (2010)

C. Corley (2004)

$\begin{array}{ll}\begin{array}{l}\text { debating possible } \\ \text { organizational }\end{array} & \begin{array}{l}\text { perceptions of } \\ \text { discrepancies and } \\ \text { actions or }\end{array} \\ \text { statements. } & \begin{array}{l}\text { possibilities for } \\ \text { change. Senior } \\ \text { Discontinuity, per se, } \\ \text { executives' }\end{array} \\ \text { was taken for } & \text { assumptions, for } \\ \text { granted, and } & \text { example, guided their } \\ \text { particular } & \text { attempts at the } \\ \text { understandings } & \text { strategic } \\ \text { formed the explicit } & \text { management of } \\ \text { premises of certain } & \text { identity }\end{array}$
meetings (p. 489)

Identity change talk valorized a certain past, present, or future organizational identity and likely denigrated or demonized others. Within everyday organizational discourse and within particular strategic meetings, identity change talk largely reinforced particular visions of the organization

Senior managers were focused on regulating the use of identity labels within the organization, and junior members of the hierarchy were concerned with relating these labels to meanings and behaviors (i.e., regulating meaning and use of language)

The paper had an participants affirmed the premise of the

meeting, in terms of shared understandings, likely served as inputs in other organizational situations (p. 85): "identity statement," which, during a key meeting, the editors chose not to revise or drop. Choices regarding stories are also commitments

Many editors felt that the identity statement, although they chose to keep it, did not reflect practices or attitudes within the
Senior managers sought to commit to a new identity and organizational style by producing and using new labels; many behaviors were unaffected

As suggested above, senior managers' shifting uses of labels led to their commitments, as expressed with these labels, being deemed 
Table 1. (Continued)

\begin{tabular}{|c|c|c|c|}
\hline Synthesis & $\begin{array}{l}\text { A. Karreman and } \\
\text { Alvesson (2001) }\end{array}$ & B. Ybema (2010) & C. Corley (2004) \\
\hline & $\begin{array}{l}\text { reinforcing particular } \\
\text { premises, } \\
\text { understandings, and } \\
\text { patterns of behavior } \\
\text { within the } \\
\text { organization }\end{array}$ & $\begin{array}{l}\text { organization. In } \\
\text { other words, they } \\
\text { found that conflicts } \\
\text { between varying } \\
\text { types of commitment } \\
\text { led to growing } \\
\text { ambiguity and } \\
\text { conflict within the } \\
\text { organization }\end{array}$ & $\begin{array}{l}\text { ambiguous by other } \\
\text { groups within the } \\
\text { organization. This } \\
\text { problem was } \\
\text { heightened by } \\
\text { conflicts between } \\
\text { labels and behaviors }\end{array}$ \\
\hline $\begin{array}{r}\text { 6. External } \\
\text { audience }\end{array}$ & $\begin{array}{l}\text { The external audience } \\
\text { that was in focus } \\
\text { throughout the } \\
\text { meeting consisted of } \\
\text { the paper's readers. } \\
\text { Much of the meeting } \\
\text { was based on } \\
\text { interpretation of the } \\
\text { relatively thin signals } \\
\text { that they had sent } \\
\text { back to the } \\
\text { organization, in the } \\
\text { form of sales figures }\end{array}$ & $\begin{array}{l}\text { Many editors were } \\
\text { concerned with the } \\
\text { impressions formed } \\
\text { by the reading public: } \\
\text { whether, for } \\
\text { example, their } \\
\text { newspaper was seen } \\
\text { as preachy and self- } \\
\text { righteous, or } \\
\text { superficial }\end{array}$ & $\begin{array}{l}\text { Senior management } \\
\text { were highly } \\
\text { concerned with } \\
\text { presenting the } \\
\text { organization to the } \\
\text { business media, and } \\
\text { responding to press } \\
\text { feedback that they } \\
\text { believed to be based } \\
\text { on misconceptions or } \\
\text { misrepresentations }\end{array}$ \\
\hline $\begin{array}{l}\text { 7. Situated } \\
\text { interpretation of } \\
\text { perceived } \\
\text { external image } \\
\text { and other factors }\end{array}$ & $\begin{array}{l}\text { As suggested above, the } \\
\text { meeting was } \\
\text { organized around } \\
\text { sales figures and } \\
\text { intended to aid in the } \\
\text { design and } \\
\text { organization of } \\
\text { content. This provided } \\
\text { an opportunity for the } \\
\text { reinforcement or } \\
\text { questioning of key } \\
\text { premises. Crucially, } \\
\text { the sales reports were } \\
\text { interpreted in light of } \\
\text { the central premise } \\
\text { that structured the } \\
\text { meeting - and a } \\
\text { number of ad hoc } \\
\text { interpretations served } \\
\text { primarily to defend } \\
\text { this premise }\end{array}$ & $\begin{array}{l}\text { As suggested by the } \\
\text { comments above, } \\
\text { Ybema states that } \\
\text { "the talk of identity } \\
\text { change and crisis in } \\
\text { this setting was } \\
\text { prompted by the } \\
\text { gradual decrease of } \\
\text { revenues from } \\
\text { subscription and } \\
\text { advertising and the } \\
\text { shared assumption of } \\
\text { having an } \\
\text { increasingly negative } \\
\text { reputation" (p. 497) }\end{array}$ & $\begin{array}{l}\text { As noted above, senior } \\
\text { executives were very } \\
\text { concerned with the } \\
\text { presentation of } \\
\text { the organization in } \\
\text { the media. More } \\
\text { junior members of } \\
\text { the hierarchy, } \\
\text { however, did not } \\
\text { consider media } \\
\text { presentation } \\
\text { particularly } \\
\text { important }\end{array}$ \\
\hline
\end{tabular}


Table 1. (Continued)

\begin{tabular}{|c|c|c|c|}
\hline Synthesis & $\begin{array}{l}\text { A. Karreman and } \\
\text { Alvesson (2001) }\end{array}$ & B. Ybema (2010) & C. Corley (2004) \\
\hline $\begin{array}{l}\text { 8. Organizational } \\
\text { identity }\end{array}$ & $\begin{array}{l}\text { Implicitly, the meeting } \\
\text { offered an } \\
\text { opportunity for } \\
\text { participants to } \\
\text { negotiate a sense of } \\
\text { organizational } \\
\text { identity with } \\
\text { reference both to } \\
\text { members' behavior } \\
\text { and key premises and } \\
\text { to the expectations } \\
\text { and desires of key } \\
\text { audiences }\end{array}$ & $\begin{array}{l}\text { Identity change talk } \\
\text { was focused both on } \\
\text { altering the behaviors } \\
\text { and choices of } \\
\text { organizational } \\
\text { members and on } \\
\text { altering the } \\
\text { perception of the } \\
\text { organization from } \\
\text { without }\end{array}$ & $\begin{array}{l}\text { The groups understood } \\
\text { different aspects of } \\
\text { the organization to } \\
\text { be central to its } \\
\text { identity. All were } \\
\text { concerned with } \\
\text { "reality" and } \\
\text { "image," however; } \\
\text { though they had } \\
\text { different thresholds } \\
\text { at which they tended } \\
\text { to react to outside } \\
\text { feedback }\end{array}$ \\
\hline Synthesis & $\begin{array}{l}\text { D. Barge, Lee, Maddux, } \\
\text { Nabring, and Townsend } \\
\text { (2008) }\end{array}$ & $\begin{array}{c}\text { E. Corley and } \\
\text { Gioia (2004) }\end{array}$ & F. Tripsas (2009) \\
\hline Outline of the case & $\begin{array}{l}\text { This paper focuses on } \\
\text { the ways in which a } \\
\text { collective of Native } \\
\text { American Colleges } \\
\text { and Universities, } \\
\text { related stakeholders, } \\
\text { and their associated } \\
\text { consultants managed } \\
\text { a set of awkward } \\
\text { dualities (inclusion- } \\
\text { exclusion, } \\
\text { preservation-change, } \\
\text { and centrality-parity) } \\
\text { during the } \\
\text { development of } \\
\text { strategic technology } \\
\text { plans }\end{array}$ & $\begin{array}{l}\text { This paper } \\
\text { investigates the } \\
\text { processes of } \\
\text { identity ambiguity } \\
\text { and change within a } \\
\text { global technology } \\
\text { service provider } \\
\text { recently spun-off } \\
\text { from its parent } \\
\text { identity }\end{array}$ & $\begin{array}{l}\text { This paper examines } \\
\text { the relationship } \\
\text { between changes } \\
\text { in technology and } \\
\text { identity within a } \\
\text { "digital } \\
\text { photography } \\
\text { company," } \\
\text { making the } \\
\text { transition to a } \\
\text { "flash memory } \\
\text { media company" }\end{array}$ \\
\hline $\begin{array}{l}\text { 1. Organizational } \\
\text { style }\end{array}$ & $\begin{array}{l}\text { The ultimate aim of the } \\
\text { Circle of Prosperity } \\
\text { Initiative was to } \\
\text { encourage new ways } \\
\text { of interrelating } \\
\text { between Indian Tribal } \\
\text { Colleges and } \\
\text { Universities (TCUs) }\end{array}$ & $\begin{array}{l}\text { As the spin-off of the } \\
\text { organization led to } \\
\text { growing identity } \\
\text { ambiguity, a large } \\
\text { part of what was } \\
\text { lost was the sense of } \\
\text { "the meanings } \\
\text { associated with }\end{array}$ & $\begin{array}{l}\text { The situational } \\
\text { premises within } \\
\text { the organization } \\
\text { guided strategic } \\
\text { action and } \\
\text { gathered together } \\
\text { into a relatively } \\
\text { coherent style with }\end{array}$ \\
\hline
\end{tabular}


Table 1. (Continued)

\begin{tabular}{|c|c|c|c|}
\hline Synthesis & $\begin{array}{l}\text { D. Barge, Lee, Maddux, } \\
\text { Nabring, and Townsend } \\
\text { (2008) }\end{array}$ & $\begin{array}{l}\text { E. Corley and } \\
\text { Gioia (2004) }\end{array}$ & F. Tripsas (2009) \\
\hline & $\begin{array}{l}\text { and other } \\
\text { organizations. The } \\
\text { communication } \\
\text { exercises used were } \\
\text { intended, } \\
\text { proximately, to help } \\
\text { the universities } \\
\text { manage the dualities } \\
\text { that would emerge } \\
\text { during the strategic } \\
\text { planning process }\end{array}$ & $\begin{array}{l}\text { their identity labels } \\
\text { and what those } \\
\text { meanings meant in } \\
\text { regard to the } \\
\text { company's } \\
\text { positioning in its } \\
\text { market space"' (p. } \\
\text { 186) - the things on } \\
\text { which it focused, } \\
\text { the other } \\
\text { organizations to } \\
\text { which it was } \\
\text { related, and its style } \\
\text { of action }\end{array}$ & $\begin{array}{l}\text { regard to the } \\
\text { allocation of } \\
\text { attention and to } \\
\text { organizational } \\
\text { action. Early on, } \\
\text { the key premise of } \\
\text { a focus on digital } \\
\text { photography } \\
\text { affected even the } \\
\text { topics of everyday } \\
\text { conversation as } \\
\text { well as marketing } \\
\text { and decision- } \\
\text { making }\end{array}$ \\
\hline $\begin{array}{l}\text { 2. Situational } \\
\text { premises }\end{array}$ & $\begin{array}{l}\text { The dualities all reflect } \\
\text { the potential conflict } \\
\text { between various } \\
\text { premises regarding } \\
\text { the appropriate } \\
\text { manner of behavior } \\
\text { culturally and in the } \\
\text { light of task } \\
\text { requirements } \\
\text { Negotiation took } \\
\text { place to synthesize or } \\
\text { connect these } \\
\text { premises, and also to } \\
\text { develop new, shared } \\
\text { premises. }\end{array}$ & $\begin{array}{l}\text { Social referent } \\
\text { change, temporal } \\
\text { identity } \\
\text { discrepancies, and } \\
\text { construed external } \\
\text { image discrepancies } \\
\text { all contributed to } \\
\text { identity ambiguity - } \\
\text { which was both a } \\
\text { condition in which } \\
\text { there were not clear } \\
\text { premises for } \\
\text { decision-making } \\
\text { and the guidance of } \\
\text { behavior, and a } \\
\text { premise in its own } \\
\text { right, which } \\
\text { entailed a perceived } \\
\text { sense-giving } \\
\text { imperative }\end{array}$ & $\begin{array}{l}\text { As suggested above, } \\
\text { the organization } \\
\text { was characterized } \\
\text { by a set of largely } \\
\text { taken-for-granted } \\
\text { assumptions, } \\
\text { which became } \\
\text { explicit when } \\
\text { challenged or } \\
\text { undercut by } \\
\text { organizational } \\
\text { action or changing } \\
\text { circumstances. } \\
\text { These premises } \\
\text { guided many key } \\
\text { strategic decisions }\end{array}$ \\
\hline $\begin{array}{l}\text { 3. Strategizing and } \\
\text { decision-making: } \\
\text { Discursive and } \\
\text { conversational } \\
\text { regulation }\end{array}$ & $\begin{array}{l}\text { Communication } \\
\text { methods such as the } \\
\text { circulation of } \\
\text { minutes, the use of } \\
\text { feedback channels } \\
\text { and particular } \\
\text { lexicons, as well as the } \\
\text { careful design of }\end{array}$ & $\begin{array}{l}\text { The sense-giving } \\
\text { imperative was } \\
\text { partly based on the } \\
\text { need to regulate } \\
\text { identity tensions in } \\
\text { organizational } \\
\text { discourses. } \\
\text { Furthermore, label }\end{array}$ & $\begin{array}{l}\text { Communication } \\
\text { patterns within the } \\
\text { organization were } \\
\text { highly significant: } \\
\text { managers' } \\
\text { communications } \\
\text { and actions either } \\
\text { reinforced or, }\end{array}$ \\
\hline
\end{tabular}


Table 1. (Continued)

\begin{tabular}{|c|c|c|c|}
\hline Synthesis & $\begin{array}{l}\text { D. Barge, Lee, Maddux, } \\
\text { Nabring, and Townsend } \\
\qquad(2008)\end{array}$ & $\begin{array}{l}\text { E. Corley and } \\
\text { Gioia (2004) }\end{array}$ & F. Tripsas (2009) \\
\hline & $\begin{array}{l}\text { opportunities for } \\
\text { interaction all allowed } \\
\text { for revelation, } \\
\text { statement, } \\
\text { challenging, and } \\
\text { defense of the } \\
\text { premises of the } \\
\text { various groups }\end{array}$ & $\begin{array}{l}\text { confusion and the } \\
\text { meaning void (both } \\
\text { features of identity } \\
\text { ambiguity) reflected } \\
\text { the perceived need } \\
\text { for the suppression } \\
\text { of alternatives in } \\
\text { favor of one } \\
\text { dominant identity }\end{array}$ & $\begin{array}{l}\text { purposefully or } \\
\text { accidentally, } \\
\text { challenged the } \\
\text { prevailing identity } \\
\text { and premises }\end{array}$ \\
\hline 4. Commitments & $\begin{array}{l}\text { Participants in the } \\
\text { prosperity game } \\
\text { developed joint action } \\
\text { plans that signaled } \\
\text { their intentions and } \\
\text { capacities to players } \\
\text { drawn from their real } \\
\text { organizational } \\
\text { environment. The last } \\
\text { stage also involved } \\
\text { formal finalization of } \\
\text { a strategic plan by the } \\
\text { TCUs }\end{array}$ & $\begin{array}{l}\text { The demand for } \\
\text { senior executives to } \\
\text { demonstrate the } \\
\text { concrete meanings } \\
\text { behind proposed } \\
\text { identity labels led to } \\
\text { a series of } \\
\text { behavioral } \\
\text { commitments on } \\
\text { their part. Branding } \\
\text { efforts also reflected } \\
\text { lexical } \\
\text { commitments to a } \\
\text { certain } \\
\text { organizational } \\
\text { identity }\end{array}$ & $\begin{array}{l}\text { Early on, the } \\
\text { organization made } \\
\text { a continual series } \\
\text { of commitments to } \\
\text { its identity as "the } \\
\text { digital } \\
\text { photography } \\
\text { company" - in } \\
\text { everyday } \\
\text { conversation, } \\
\text { marketing, and } \\
\text { strategic behavior. } \\
\text { Later, these } \\
\text { commitments } \\
\text { changed and } \\
\text { drove a shift in } \\
\text { organizational } \\
\text { identity }\end{array}$ \\
\hline $\begin{array}{l}\text { 5. Reinforcement } \\
\text { and ambiguation }\end{array}$ & $\begin{array}{l}\text { One element of the } \\
\text { initiative was to help } \\
\text { the players } \\
\text { understand the goals } \\
\text { and capabilities of } \\
\text { other organizations in } \\
\text { their environment. } \\
\text { The process of } \\
\text { signaling, during the } \\
\text { prosperity game and } \\
\text { other stages of the } \\
\text { initiative, reinforced } \\
\text { or altered (or } \\
\text { potentially rendered } \\
\text { ambiguous) the }\end{array}$ & $\begin{array}{l}\text { Ambiguity arose } \\
\text { based on a number } \\
\text { of factors, including } \\
\text { the discrepancies } \\
\text { between past, } \\
\text { present, and future } \\
\text { identities that } \\
\text { emerged from } \\
\text { certain lexical } \\
\text { commitments and } \\
\text { discrepancies } \\
\text { between lexical and } \\
\text { behavioral } \\
\text { commitments. This } \\
\text { ambiguity appears }\end{array}$ & $\begin{array}{l}\text { As suggested above, } \\
\text { the commitments } \\
\text { made by the } \\
\text { organization at } \\
\text { first reaffirmed } \\
\text { and later } \\
\text { challenged the } \\
\text { organization's } \\
\text { identity as a } \\
\text { digital } \\
\text { photography } \\
\text { company. As the } \\
\text { shift began, } \\
\text { members' felt a } \\
\text { significant degree }\end{array}$ \\
\hline
\end{tabular}


Table 1. (Continued)

\begin{tabular}{|c|c|c|c|}
\hline Synthesis & $\begin{array}{l}\text { D. Barge, Lee, Maddux, } \\
\text { Nabring, and Townsend } \\
\text { (2008) }\end{array}$ & $\begin{array}{l}\text { E. Corley and } \\
\text { Gioia (2004) }\end{array}$ & F. Tripsas (2009) \\
\hline & $\begin{array}{l}\text { perceived identities of } \\
\text { the players }\end{array}$ & $\begin{array}{l}\text { to have been felt } \\
\text { both internally and } \\
\text { externally }\end{array}$ & $\begin{array}{l}\text { of ambiguity, and } \\
\text { it is only after the } \\
\text { new message was } \\
\text { reinforced over } \\
\text { time that things } \\
\text { settled once again }\end{array}$ \\
\hline $\begin{array}{l}\text { 6. External } \\
\text { audience }\end{array}$ & $\begin{array}{l}\text { Several aspects of the } \\
\text { initiative were } \\
\text { designed to make the } \\
\text { players more aware of } \\
\text { their audiences and } \\
\text { potential partners }\end{array}$ & $\begin{array}{l}\text { Analysts, customers, } \\
\text { and the business } \\
\text { media all remained } \\
\text { a consistent focus } \\
\text { for senior } \\
\text { managers attention }\end{array}$ & $\begin{array}{l}\text { Especially during the } \\
\text { shift in identity, } \\
\text { the company put } \\
\text { in a great deal of } \\
\text { effort into } \\
\text { managing investor } \\
\text { and media } \\
\text { perceptions of } \\
\text { their new identity }\end{array}$ \\
\hline $\begin{array}{l}\text { 7. Situated } \\
\text { interpretation of } \\
\text { perceived } \\
\text { external image } \\
\text { and other factors }\end{array}$ & $\begin{array}{l}\text { Other aspects of the } \\
\text { initiative were } \\
\text { designed to encourage } \\
\text { feedback, and careful } \\
\text { attention to } \\
\text { interpreting and } \\
\text { understanding this } \\
\text { feedback }\end{array}$ & $\begin{array}{l}\text { Individuals' } \\
\text { perceptions of } \\
\text { external feedback } \\
\text { weakened their } \\
\text { sense of a stable or } \\
\text { definite } \\
\text { organizational } \\
\text { identity and set of } \\
\text { premises for } \\
\text { managing their own } \\
\text { activities within the } \\
\text { organization }\end{array}$ & $\begin{array}{l}\text { External feedback } \\
\text { encouraged a } \\
\text { focus on a clearly } \\
\text { presented and } \\
\text { focused identity } \\
\text { and behavioral } \\
\text { orientation: } \\
\text { whether as a } \\
\text { digital } \\
\text { photography } \\
\text { company or a } \\
\text { memory company }\end{array}$ \\
\hline $\begin{array}{l}\text { 8. Organizational } \\
\text { identity }\end{array}$ & $\begin{array}{l}\text { The initiative stressed } \\
\text { the need to maintain } \\
\text { Indian culture while } \\
\text { altering } \\
\text { organizational image } \\
\text { to allow and sustain } \\
\text { collaboration. This } \\
\text { blending of concerns } \\
\text { of disposition and } \\
\text { perception forms an } \\
\text { identity management } \\
\text { process }\end{array}$ & $\begin{array}{l}\text { Members developed a } \\
\text { sense of "who we } \\
\text { are" as an } \\
\text { organization that } \\
\text { entails a particular } \\
\text { place for the } \\
\text { organization in its } \\
\text { environment, a } \\
\text { particular lexicon } \\
\text { and set of } \\
\text { behaviors, and } \\
\text { which is closely } \\
\text { bound to a specific } \\
\text { external image }\end{array}$ & $\begin{array}{l}\text { Throughout, } \\
\text { members (and } \\
\text { others) were } \\
\text { concerned with the } \\
\text { image of the } \\
\text { company as } \\
\text { understood by } \\
\text { both internal and } \\
\text { external audiences } \\
\text { and with the } \\
\text { consistency of the } \\
\text { behaviors and } \\
\text { dispositions } \\
\text { associated with } \\
\text { this image }\end{array}$ \\
\hline
\end{tabular}


that ethos is embedded and which make up everyday organizational life and distinguish organizations from one another. Defined in these terms, an organization's style is composed of a complex and distributed set of situational premises that guide the organizations' members during specific episodes of activity and the various commitments that are made as a result. The domain of style, thus, may be characterized by the questions of "how people do things around here" or "what it's like here." In this sense, the domain of organizational style bears some similarity to certain formulations of culture (e.g., Knorr Cetina, 1999); however, our notion of style differs from typical conceptions of organizational culture in that it does not entail internalization of social rules or roles. Organizational members need not internalize particular rules to enact an organization's style; rather, they only need to know what sort of rhetorical and material tools they may use to get their jobs done and pursue their own interests within the organization (see Swidler, 1986). This will be further clarified in the discussion later.

The second domain we refer to as the organization's external audience. We use audience to refer to the various constituencies that in some way evaluate the organization and their accompanying perceptions of the organization. Various external audiences actively interpret the actions and statements of the organization and communicate their corresponding evaluations, expectations, or attitudes through actions or statements of their own. If the first domain refers to the organization's activities and its members' guiding interpretations, the second refers to external perceptions of that organization - to the characteristic styles of life, organizational behavior, and member behavior identified by others, based on principles abstracted from their ongoing experiences of the organization.

The domain of organizational style and that of external audience interact with each other continuously. We refer to this sphere of interaction - our third and final domain - as organizational identity. To clarify this point, we see organizational identity as a composite of the organization's style and the expectations (and images) formulated and described by its various external audiences. An organization's identity is perceived internally by its members as the organization's self-definition, as negotiated with the various audiences to whom it is projected externally (and internally). That is, organizational identity is formed of a set of characteristics and personality traits that are perceived to define what is most central, enduring, and distinctive about that organization (Albert \& Whetten, 1985), and at the same time, these personality traits are shaped by audiences' expectations of what an organization of this type should do and how it should be. Although an organization's identity, like any boundary object (see Star \& Griesemer, 
1989), may be taken up for different purposes and assigned different meanings depending on the situation, an organization's identity also has some sense of permanence that distinguishes the organization's position in the world. This relative permanence is a product of the audiences' demands for organizational reliability and accountability (Hannan and Freeman 1989) and of the organization's own need to perpetuate itself. and Schultz (2002) when they argue that, just as individual identity reflects the individual's dual position as a subject and object (an "I" and a "me"), organizational identity reflects the dual position of the organization. ${ }^{11}$ Each of the two previously defined domains influences the other and thus shapes organizational identity, in the same way that Mead (1934) envisaged the emergence of individual selves from processes of a reciprocal translation between a public audience and a self-understanding of the individual (Pratt \& Kraatz, 2009). The organization cannot escape the evaluations made of it by its various audiences, yet neither can the audiences make sense of the organization without some sort of understanding of the organization's being. ${ }^{12}$ The product of this interaction - that is, of figuring out who the organization is, as we consider its members' activities and interpretations and external audiences' perceptions of it - is the organization's identity.

Although we make certain terminological choices that set apart our view from others, our process model is consistent with influential treatments of organizational identity (Hatch \& Schultz, 2002; Whetten \& Mackey, 2002) and sociological theories of categorical identity (e.g., Zuckerman, 1999). One advantage to our approach is that it integrates perspectives that emphasize the processual nature of identity construction (e.g., Hatch \& Schultz, 2002) with those that emphasize the durable and noun-like characteristics of identity (e.g., King et al., 2010). This integration of perspectives is necessary to understand how individuals within an organization come together to reproduce what, to particular external audiences, appears to be a stable organizational self, when, internally, wide variation in beliefs and dispositions may exist. Understanding this reciprocal process illuminates how collective intentionality emerges even in the absence of strong socialization or structurally induced conformity.

\section{Style}

As suggested earlier, style refers to the rhetorical and material activities that take place within the organization or on its behalf. Just as an individual may 
give an automatic physical response to a well-placed tap upon the knee, a perhaps more considered response to a kick in the shins, and a different response to a whispered endearment, the actions and responses of organizations are highly contextual, depending on what is done, when, how, and to which part of its entity. Perceptiveness, acuity, and activity and responsiveness can be hierarchically specific (Corley, 2004; see Table 1, C1-C8) and are also likely to reflect the particular chain, sequence, or set of situations in which particular individuals or organizational subgroups have been engaged (Karreman \& Alvesson, 2001; see Table 1, A5). That is to say, style is complex rather than monolithic. Rather than a conceptual or practical problem, this is likely an unavoidable feature of social and organizational life. Individuals are acclimatized to this feature of their organizations and possess "cognitive maps" that allow them to navigate the internal order of the organization, making predictions about how a member of the organization will perceive an action and how they will respond to that action (Jackall, 1988).

One key aspect of organizational style consists of the various situational premises in play across the organization. These are the assumptions or presuppositions that inform and structure particular organizational situations or episodes of interaction. These premises may be either implicit or explicit. This includes premises regarding the nature of the situation itself, such as what it is "about" and what styles of interaction and cognition are appropriate. And it also includes premises about the nature of the topic - its importance, for example, or the intentions, interests, or general characteristics of the other entities involved (such as consumers, suppliers, regulators, or products) - and the appropriate styles of action and reaction at the individual, group, or organizational level. Of particular importance, situational premises include assumptions about the organization's purposes, characteristics, opportunities, and vulnerabilities. When these assumptions are made explicit, they may call into play specific obligations and responsibilities of participants in relation to the organization as a collective entity (e.g., a professional membership organization is obligated to inform its members of weighty financial expenses).

Although the concept of the situational premise is not made explicit in the literature on organizational identity - with one notable exception among our data sources (Karreman \& Alvesson, 2001; see Table 1, A2-A5) - the concept encompasses many of the concerns highlighted in the ethnographies. To give a clear idea of its content, we refer to Karreman and Alvesson (2001), who describe a strategic meeting designed to reflect the premise that news bills sell newspapers. The meeting is set up so that participants can identify good news bills - leading stories and front pages that gained good 
sales for the paper - and bad ones, which undersold. The discussion is based around the qualities and design that make an idea newsworthy and sellable. When, at one point during the meeting, a member questions the premise, his point is quickly and aggressively challenged and dismissed, despite the clear availability and visibility of data supporting his view. The quick dismissal reflects participants' strong assumptions that their newspaper just is about selling and distributing news. This is perhaps the clearest example of an important situational premise in play. Other sources provide further illustrations. Perceived discrepancies between external and internal perceptions may be one form of situational premise, forming the backdrop for a "need for change" (Corley, 2004; Corley \& Gioia, 2004; Ybema, 2010; see Table 1, C2, E2, and B1-B2, respectively). So too, "a culture of collaboration" may be reflected in the premises of particular organizational situations (Barge et al., 2008; see Table 1, D1-D2) and the existence of routine procedures may likewise lead to a certain set of situational premises regarding what a situation, and the organization, is about and what it should entail (Tripsas, 2009; see Table 1, F1-F2).

Two points should be emphasized. First, premises may be drawn from a number of sources, but we are primarily concerned with common premises, as reflected in the example from Karreman and Alvesson (2001; see Table 1, A2). Secondly, premises are situationally specific and may be influenced by individuals' positions within the organizational hierarchy or division (Corley, 2004; see Table 1, C2). This said, some premises are more or less maintained or consistent across situations and divisions. Consistency likely results in a relatively stable sense of organizational purpose and context, whereas inconsistency is likely to damage or reduce such a sense, leading to more open negotiation of the organization's style.

Situational premises inform the processes of strategizing, by structuring the episodes in which both formal and informal strategy-making and decision-making occur. Crucially, they play out through processes of discursive/conversational regulation. That is, the premises are implicitly or explicitly associated with scripts, ${ }^{13}$ which participants will seek to maintain to defend the premise and the associated sense of the situation or even to challenge others' questioning of a premise (Karreman \& Alvesson, 2001; see Table 1, A2-A3 and A7). ${ }^{14}$ This may entail regulation of local conversations or more general regulation of discourse through attempts to impose specific labels to describe organizational purpose, nature, or circumstances (Corley, 2004; Corley \& Gioia, 2004; see Table 1, C3-C4, C6, and E2-E4, respectively) or through attempts to design situations to reflect certain premises and to delimit the possibilities for others. For 
instance, through the design of the news bills meeting, conversation unfolds in a manner that renders the news bill central and connects it closely to sales (Karreman \& Alvesson, 2001; see Table 1, A7). As suggested earlier, these forms of regulation are especially observable in strategic meetings (Karreman \& Alvesson, 2001; see Table 1, A8), but discursive/conversational regulation, and particularly lapses in regulation, can also involve grumbling in the corridors that may undercut any members' favored premises or even attempts to deploy new top-down, official narratives (Corley, 2004; Ybema, 2010; see Table 1, C3, C5, and B3, respectively). ${ }^{15}$

Importantly, strategic decision-making ultimately leads to commitments, whether in the form of actions or statements. These actions and statements, whether intended to or not, create expectations or reinforce existing expectations about the organization's being (Selznick, 1957). They send signals regarding the organization's orientation to action, regarding its characteristics and quality, and thereby reinforce or undercut one or another component of the organization's style. These signals may be received by organizational members (and hence enter into future situational premises) or by external audiences (hence affecting the ways in which those constituencies will understand, evaluate, and interact with the organization). Commitments, of course, may vary significantly in strength and cost. Commitments that are more costly and irreversible are also likely to be perceived as stronger signals of the organization's true self (King et al., 2010; Whetten, 2006). They can include statements that only symbolically reflect the intended character of the organization (such as product advertisements or recruitment materials), statements of purpose, or ethical codes, or they may be explicit identity statements that attempt to summarize these characteristics (as considered in the case presented by Ybema, 2010; see Table 1, B4-B5). Likewise, they may cover everyday actions, including issues such as the degree of concern for worker safety, or customer satisfaction evinced during work, or the attention given to particular types of issues (as in Karreman \& Alvesson, 2001; see Table 1, A1 and A4), or more "one-off" decisions such as the spin-off of a division (the management of which is discussed by Corley, 2004, and Corley \& Gioia, 2004, alongside other commitments - see Table 1, C4, and E1 and E4, respectively) or a move away from an old market and into a new one (as discussed in Tripsas, 2009; see Table 1, F1 and F4). In each case, these commitments reinforce, elaborate, or challenge an organization's style.

Over time, these commitments may mutually reinforce one another, leading members and external audiences to develop relatively stable 
expectations of organizational style, or they may seem to contradict one another - making the style appear ambiguous or mutable. Elements of this process of reinforcement and ambiguation may include continued or interrupted commitment to formal routines (Tripsas, 2009; see Table 1, F1-F5) or to particular styles of strategic analysis (Corley, 2004; Corley \& Gioia, 2004; Karreman \& Alvesson, 2001; see Table 1, C5, E5, and A5, respectively) or to particular labels for describing the organization and its activities (Corley \& Gioia, 2004; Tripsas, 2009; see Table 1, E1 and E5, and F3 and F5, respectively). The key point is that the various commitments made through repeated or one-off actions lead to either a consistent or inconsistent image of the organization for external audiences.

\section{External Audience}

As suggested earlier, the ethnographies synthesized in this chapter focus primarily on the domain of the organization's style. That said, they do point to some of the interactions between this domain and that of external audiences. The audience domain is composed of various constituencies of an organization who actively evaluate, communicate with, and interact with the organization (Zuckerman, 1999). Organizations communicate with their audiences through actions and statements, signaling commitments about their style in the process, and, in turn audiences evaluate these commitments, sometimes spurring direct responses or actions (e.g., consumers decide to boycott a retailer when they learn that it uses unfair hiring practices). Although our sources focused primarily on the consequences of this process, they do indicate the concern of organizations with how their commitments will be understood and how this will affect the actions and reactions of the various audiences (Corley, 2004; Corley \& Gioia, 2004; Tripsas, 2009; Ybema, 2010; see Table 1, C6-C7, E6-E7, F6-F7, and B6-B7, respectively).

This concern is perhaps more clearly evident in the importance of an organization's external image and reputation. The image of the organization consists of the various claims that people make about the identity of the organization, and a reputation is an audience's generalized belief about an organization's performance or adherence to particular standards (King \& Whetten, 2008; Whetten \& Mackey, 2002). Gioia, Schultz, and Corley (2000) suggest that concerns about discrepancies in the organization's external image - how are we seen? and how do we want to be seen? - may motivate change efforts or, when audiences' assessments of the 
organization's image align, may reinforce existing courses of action. For instance, if we perceive ourselves as misrepresented and in need of an improved reputation, we may make an effort to change our behaviors or our self-presentation. Our meta-analysis suggests that both images and reputation provide feedback into the situational premises structuring many aspects of organizational activity. Ybema (2010) gives one example of this mechanism of transmission in the newspaper that he studied (see Table 1, B7). One group of the editorial staff "internalized the negative image that the public was assumed to have ... labeling their own paper as 'predisposed', 'patronizing', 'cynical', 'predictable', and 'moralizing"' (p. 490). This negative public image formed the backdrop of a discourse that called the paper to a brighter future and an "open and newsy" orientation (p. 490). Concerns about the image and reputation of the organization became premises in their own right, along with the presumed imperative for change. Similarly, in Corley (2004) and Corley and Gioia (2004), senior executives' beliefs that the media was misinterpreting or misrepresenting the organization in a negative manner became an important situational premise that contributed to changes in the organization's behavior and discourse (see Table 1, C7 and E7, respectively).

Other forms of environmental feedback may also enter into the situational premises characterizing the organization. More specifically, they will enter into these premises through a process of situated interpretation. As the actions and statements of the organization lead to reactions on the part of other actors within its environment, these reactions are interpreted through particular lenses by the various groups within the organization, not only as indicators of external image (Corley, 2004; Corley \& Gioia, 2004; see Table 1 C7 and E7, respectively) but also as indicators of the status and nature of particular intra-organizational situations (Karreman \& Alvesson, 2001; see Table 1, A6-A7). For example, negative media feedback can lead to serious concern among senior management, and a desire for a clear response, while appearing as an irrelevance or minor irritation to more junior staff (Corley, 2004; see Table 1, C1, C3, and C7), and the premises of a particular meeting may largely determine whether good or bad sales figures are understood as reflecting quality, speed of production, or factors such as the inclusion or exclusion of a TV guide (as in the case presented by Karreman \& Alvesson, 2001). The lenses that situate a group's specific interpretation may derive from factors such as their particular position in the hierarchy (Corley, 2004; see Table 1, C1 and C7) or their positions in internal debates - such as those regarding the temporal trajectory of the organization (Ybema, 2010; see Table 1, B1 and B7). For many decisions, 
varying interpretations and prescriptions may ultimately be decided on grounds of organizational identity.

\section{Organizational Identity}

We understand organizational identity as the organizational character or personality that arises from the interaction of the organization's style and the feedback from its external audience. It reflects the symbolic power of the situational premises within the organization and the organization's consequent commitments - specifically, derived from the experiences and expectations generated by commitments - and is informed and reinforced by external images and the organization's reputations. To put this another way: organizational identity is the joint product, on the one hand, of organizational members' situational premises and the consequent symbolically laden organizational commitments that structure how external audiences perceive and evaluate the organization, and on the other hand, of the multiple external perceptions and evaluations that in turn structure members' situational premises and future organizational commitments. Identity depicts the organization, or describes "who the organization is," for the various groups that factor the organization into their decision-making internally and externally. Accordingly, it may be more or less coherent or unified, depending on the stability of audiences' perceptions and of the situational premises deployed by organizational members (Zuckerman, 2004).

Returning to our analogy of the individual, identity may be managed in a way that coheres reasonably within a "personality" or it may splinter and fracture into "personality disorder."16 Environmental disruptions may significantly alter audience expectations, leading to the genesis of new, conflicting situational premises and responses by the organization that lead to competing, contradictory commitments. For example, a non-profit organization may adopt managerialist strategies in order to meet external demands for accountability and efficiency, which may, in turn, lead to conflicts with commitments to mission-specific ideals (Clemens \& Guthrie, 2010). Despite environmental turbulence, organizations face external and internal pressures to resist identity change (Tripsas, 2009; see Table 1, F7F8). Both externally and internally, past commitments incline the audiences to expect continuity in the organization's actions and communications (Corley \& Gioia, 2004; Karreman \& Alvesson, 2001; Tripsas, 2009; see Table 1, E1-E8, A3-A4 and A7, and F7-F8, respectively). Sudden 
departures from the expected pattern of activity may cause audiences to revoke their support and resources. Thus, to improve their survival chances, organizations may seek to root out inconsistencies and produce coherent identities (Zuckerman, 2004, 2010). Moreover, past commitments may imply significantly high switching costs, which will inhibit reversing those commitments (Whetten, 2006). Thus, even when facing pressure to adapt to their environment and change their identities, organizations face external and internal constraints that help to produce and maintain continuity in the organization's identity. This continuity may ensure relative stability in the organization's style and fairly predictable reactions among the organization's external audience; enabling strategic decision-making to occur without any great surprises among the involved organizational agents (Karreman \& Alvesson, 2001; see Table 1, A3-A4, A7). Although the decisions themselves are never fully predictable the process and discussion leading up to the decision follow a similar pattern because those decisions are based on the same situational premises and commitments and occur in the same audience context as those earlier decisions.

In short, internally reengineering their identities is often costly enough that most organizations seem only to make such changes in relatively dire circumstances or in the face of significant and determined internal or external pressure (see, e.g., Tripsas, 2009; see Table 1, F5 and F8). In such circumstances, however, temporal discontinuities may be emphasized and exaggerated as a way of distancing the organization from its past, and casting it as being on the path to success (following a past or prospective intervention). The case of the newspaper studied by Ybema (2010) provides an exemplary instance of this (see Table 1, B2).

Whether highly stable, stable within distinctive and contrastable periods of time, or somewhat more fluid, organizational identity is the recognizable entitativity and nature of the organization that enables and maintains collective intentionality itself. From the outside looking in, audiences perceive the identity of an organization as the impetus for action and reaction (Tripsas, 2009; see Table 1, F6-F8). From the inside looking out, organizational members project their strategic decisions onto the identity of the organization (Corley \& Gioia, 2004; Tripsas, 2009; Ybema, 2010; see Table 1, E1 and E8, B1, B6, and B8, and F1, F4, F5, and F8, respectively). Thus, identity enables the appearance of coherent action while also structuring internal deliberation over strategic decisions, even if the individual inputs to that action are quite heterogeneous. Organizational identity provides the grounds for collective intentionality. That is, intentionality - in the sense of a coherent orientation to action on the part of a 
given collective - reflects both a relatively stable set of dispositions and expectations and the more or less coherent and identifiable identity that anchors them.

\section{CONCLUSION}

Within both sociology and organization theory, collective intentionality is implicit in our understanding of how groups and organizations function. Despite its analytic centrality, collective intentionality, and organizational intentionality in particular, has been the subject of relatively little explicit theorization and research. Most accounts of organizational structure privilege rules, routines, and incentive structures, or, in another tradition, norms and relatively homogenous and static cultures. Both rely on overly deterministic explanations for how organizations "get inside the heads" of their members. The former set of explanations runs afoul of the unavoidable incompleteness of regulatory systems, alongside their ambiguity, manipulability, and frequent internal inconsistency. The latter risks an over-socialized conception of human agents, where the organizational members surrender their individuality and are imprinted relatively unproblematically with the organizational culture. Through a meta-ethnographic and largely inductive study, we have sought to open up a new set of explanations - which take account of the rich ethnographic data already available. Our focus on the role of organizational identity in strategizing has allowed us to demonstrate how collective intentionality emerges in organizations without organizations' members being fully socialized to share the same interests, preferences, or beliefs or being fully governed by a quasi-deterministic and hierarchical structure. Our broad, conceptual argument is that organizations are a particular type of semi-independent actor with distinctive identities that influence, and are influenced by, organizational strategizing and decisionmaking. This identity helps give coherence to organizational activities and to the organization itself and establishes some degree of consonance between the style of the organization and its images and reputations among its various external audiences. As such, the identity of the organization propels the activity of the organization in a semi-predictable fashion.

Crucial to our account is that identity imbues the organizational self with unity, recognizability, and entitativity. That is, organizational identity not only informs the dispositions of the organization but is also responsible for transforming them from patterns of interpretation and action to a recognizable and quasi-independent source of collective intentions. Through 
this process, the organization as a distinct self emerges - a self that others around and inside the organization recognize as real and significant in its consequences. The more the specific premises of organizational style are salient, and the more carefully they are regulated in the process of strategizing, the more easily a clear and stable sense of collective intentionality may be maintained. Reciprocally, the more diverse and complex the situational premises or the more differentiated their distribution across the organization, the less likely it may be that collective intentionality will appear clear and stable.

Given that identity delineates the organization as an actor, it provides members, audiences, and analysts with a useful analytic and predictive tool. Dennett (1987, pp. 98-99) has argued that intentionality is a "reliably predictable" explanation of many entities' behaviors, especially when we can conceivably "get inside the head" of that entity and answer the question, "what ought this creature to believe?". Understanding the identity of an organization facilitates an answer to this question. In form and function, organizational identity is very similar to the identities of individuals, which are also adaptive to audiences' perceptions and which, internally, the individual continually negotiates through choice trade-offs (e.g., part of me really wants to find a new job, but another part of me likes the stability of my current one). The choices we make as individuals have a definite consequence for our evolving identity, but we cannot make those choices in isolation from our current commitments and external expectations. We apply different situational premises to help make sense of any given choice, and we consider how those choices will look to others. In the end, we must justify our choice based on a coherent conceptualization of self. Others around us do the same. They recognize the intentionality of our choices (even if random factors ultimately determined the decision) and act upon those inferences. Organizations are no different in this regard. We can only understand an organization's strategic choices when we, the audience or its members, choose to view that choice through the lens of the organization's own identity.

Aside from drawing our attention to a largely understudied set of empirical phenomena - by foregrounding, for example, the ways in which people engage with the organization as an "it" rather than an "us" - and their interrelations with other aspects of organizational life, this approach supports or opens up some relatively novel theoretical and empirical directions. Firstly, it supports recent work in the literature on organizational identity that aims more or less explicitly at integrating the noun- and verblike qualities of organizations and their identities. As suggested by Hatch 
and Schultz (2002), identity is a process - but at the same time, it is a process that is frequently understood and experienced as relatively stable and nounlike. Our approach should help to orient further research on the ways in which the noun-like qualities of organizational identity emerge from the processes of identity formation and maintenance and the ways in which, simultaneously, they serve as inputs into those processes. Secondly, our approach also supports work that stresses the grounding of identity in material activities (e.g., Hatch \& Schultz, 2002). Identity, in the model we present, arises in large part from the interaction of a concrete set of intraorganizational material practices - in which situational premises come into play - specific organizational commitments, and the material and consequential responses from external audiences affected by those commitments. Without eliding the extreme importance of the symbolic aspects and valences of the premises, commitments, and other concepts, we emphasize the ways in which these phenomena are intertwined with material concerns, are instantiated in material settings, and are even embedded in material designs and arrangements.

Future work on collective intentionality might also investigate further how the noun-like properties of organizational actors emerge or change over time. Organizational biographies or life course models of organizations might be fruitful methods for examining the micro-social mechanisms through which organizational selves evolve and change over time; as has been done elsewhere, for individuals.

Future work ought, also, to focus on the boundary conditions and scope of the analysis presented here. Although we maintain that our model is sufficiently broad to be of high generality, idiosyncrasies in the ways that the three domains interact may vary across organizational forms - hence the call for research into organizational biographies. Comparative research on different organizational forms (e.g., corporate forms vs. social movement organizations) might also lead to adjustments within the broad contours of the model.

Further research might examine the various ways that organizations manage the feedback process between their styles and external audiences. One important factor that obviously shapes this identity management process is variation in the audiences. For example, we would predict that organizations with more points of interface - those that come into contact more frequently, with more audiences - may experience relatively more turbulence in their style and in their identity. In other words, the more "sociable" the organization, the more likely it is that its personality and character will change over time due to its experiences. This argument is analogous to the argument of technological buffering proposed by 
Thompson (1967); however, whereas Thompson suggested that firms seek to insulate their technical core from environmental influences, we would suggest that they may seek to insulate their "selves." The empirical frequency of such social buffering and its relation to the stability of identity seem analytically and practically useful objects of analysis. It is our suspicion that a region of "healthy" buffering might be identified: such that too great a concern with buffering, or with maintaining the boundaries or "purity" of the organization's identity, may result in stagnation and social dysfunction, and too little may result in instability and identity disorders. Inasmuch as identity coherence is key to maintaining collective intentionality, such confusion may disrupt the organizational self, ultimately splintering the organization into subsidiaries or new organizations. However, this potential problem also highlights what is distinctive about organizations as compared to other collective forms. Inasmuch as they are able to create stable identities, organizations are uniquely capable of surviving environmental turbulence and persist even when the original need or justification for their formation and maintenance has disappeared (e.g., witness the remarkable endurance of the Tennessee Valley Authority). The path dependence of identities enables the reproduction of organizations and their characteristics despite the fluctuating involvement and shifting nature of their memberships.

\section{NOTES}

1. Latour prefers to use the semiotic term "actant" for various reasons. For the present purposes, the distinction is not essential.

2. Such a division is inevitably schematic and somewhat simplified; it is nonetheless informative.

3. A corollary perspective is that individuals self-select into organizations with which they identify and therefore that they are pre-socialized to believe and do as the organization would have them.

4. Certain variations of this approach escape this problem. Inasmuch as they do so, however, they open up an important role for the type of explanation that we explore here (e.g., Hatch \& Schultz, 2002).

5. This is not to say that individuals should, prescriptively, be so oriented: it is a statement solely of the technical problems faced by the organization given that it possesses interests; whether these interests are socially or individually beneficial or detrimental, and whether the social form is valorized, demonized, or anything in between.

6. This approach to organizational identity, focused on its central, enduring, and distinctive nature, has of course been challenged. Some authors have suggested that 
organizational identity is actually relatively fluid (Gioia et al., 2000; Hatch \& Schultz, 2002), and others have suggested that it might be more fruitful to discuss organizational identities and the interplay between them, rather than to suppose that there is any single, definitive organizational identity to be found (Humphreys \& Brown, 2002; Sillince \& Brown, 2009). Such treatments open up a variety of interesting questions, theoretically and empirically, but they do not fundamentally challenge the notion of the organizational actor, and its involvement in group deliberation and decision-making. By analogy, just as an individual may have a more or less stable identity, or may have a number of differing identities, so too may an organizational actor. At particular points, effective invocations of individuals or organizations seem to require that their complexity and multiplicity be simplified or filtered to create a manageable level of coherence, including a sense of a credible and probably predictive link between their past, present, and future. Inasmuch as this occurs, the identity of the organizational actor comes into play and may affect decision-making and behavior - whether this identity is stable across situations, or challenged by other identities, or not.

7. Even when strategizing is focused on less ostensibly crucial concerns, it may still represent a particularly reflexive moment in organizational discourse, when the orientation of the organization as a whole is likely to be in focus.

8. EBSCO Business Source Premier, ISI Web of Knowledge, JStor, and ProQuest.

9. Academy of Management Journal, Administrative Science Quarterly, British Journal of Management, European Journal of Management, European Management Review, Journal of Management Studies, Organization Science, and Organization Studies.

10. Accordingly, we used a relatively broad definition of ethnographic work, as prolonged, analytically driven immersion in a social scene, with a focus on emic description; whether this is undertaken in the role of a participant or an observer (Hammersley \& Atkinson, 1993).

11. Although there are significant differences in emphases - and we would be skeptical, also, of the reduction of the organization's subject and object positions to those of its membership - to "we" and "us," rather than "it" (and "it").

12. We recognize, of course, that we are not the first to theorize the link between an organization's identity and its audience (e.g., Hannan, Polos, \& Carroll, 2007; Hsu, 2006; Zuckerman, 1999). Indeed, our conceptualization of identity is rooted in Mead's (1934) theory of self. However, most sociological depictions of organizational identity do not make a link between the individual organization's identity and the audience perceptions. Rather, their focus tends to be on the link between categorical membership and audience's perceptions of fit within that category (e.g., Phillips \& Zuckerman, 2001).

13. These may vary in their degree of structure - some being analogous to "themes" for improvisations.

14. These scripts might also be deployed to challenge the premises on which they are originally based.

15. The literature on organizational identity is beginning to recognize the importance of organizational discourse, and of its use to enforce particular narratives and senses of purpose, and has accordingly begun to trace some of the strategies used to build and maintain managerial hegemony (Chreim, 2005; 
Humphreys \& Brown, 2002). Our results support this emergent, but currently somewhat peripheral trend, but we focus on a broad concept of regulation and a similarly broad definition of discourse (which includes the symbolic design of material situations, to embody certain premises).

16. The generality of this definition is intentional and reflects our own sense that organizational identity is a rather complex process, reflecting the status of the organization as both a subject and an object (Hatch \& Schultz, 2002) at the same time.

\section{ACKNOWLEDGMENTS}

We would like to thank Franz Wohlgezogen, Shamus Khan, and Teppo Felin for their comments, advice, and support. Any remaining errors are our own.

\section{REFERENCES}

Albert, S., \& Whetten, D. A. (1985). Organizational identity. Research in Organizational Behavior, 7, 263-295.

Ashforth, B. E., Harrison, S. H., \& Corley, K. G. (2008). Identification in organizations: An examination of four fundamental questions. Journal of Management, 34, 325-374.

Ashforth, B. E., \& Mael, F. A. (1989). Social identity theory and the organization. Academy of Management Review, 14, 20-39.

Barge, J. K., Lee, M., Maddux, K., Nabring, R., \& Townsend, B. (2008). Managing dualities in planned change initiatives. Journal of Applied Communication Research, 36, 364-390.

Bechky, B. A. (2003). Object lessons: Workplace artifacts as representations of occupational jurisdiction. American Journal of Sociology, 109, 720-752.

Beyer, J. M., \& Trice, H. M. (1987). How an organization's rites reveal its culture. Organizational Dynamics, 15/4, 5-25.

Brown, A. D. (2006). A narrative approach to collective identities. Journal of Management Studies, 43, 731-753.

Brown, A. D., \& Humphreys, M. (2006). Organizational identity and place: A discursive exploration of hegemony and resistance. Journal of Management Studies, 43, 231-257.

Campbell, R., Pound, P., Pope, C., Britten, N., Pill, R., Morgan, M., \& Donovan, J. (2003). Evaluating meta-ethnography: A synthesis of qualitative research on lay experiences of diabetes and diabetes care. Social Science \& Medicine, 56, 671-684.

De Certeau, M. (1984). The practice of everyday life. London: University of California Press.

Chandler, A. D. (1993). The visible hand: The managerial revolution in American business. Boston, MA: Harvard University Press.

Chatman, J. A. (1991). Matching people and organizations: Selection and socialization in public accounting firms. Administrative Science Quarterly, 36, 459-484. 
Chreim, S. (2005). The continuity-change duality in narrative texts of organizational identity. Journal of Management Studies, 42, 567-593.

Clemens, E. S., \& Guthrie, D. (2010). Politics and partnerships: The role of voluntary associations in America's political past and present. London: University of Chicago Press.

Coleman, J. S. (1982). The asymmetric society. New York, NY: Syracuse University Press.

Corley, K. G. (2004). Defined by our strategy or our culture? Hierarchical differences in perceptions of organizational identity and change. Human Relations, 57, 1145-1177.

Corley, K. G., \& Gioia, D. A. (2004). Identity ambiguity and change in the wake of a corporate spin-off. Administrative Science Quarterly, 49, 173-208.

Dennett, D. C. (1987). The intentional stance. Cambridge, MA: MIT Press.

Dosi, G., Faillo, M., \& Marengo, L. (2008). Organizational capabilities, patterns of knowledge accumulation and governance structures in business firms: An introduction. Organization Studies, 29, 1165-1185.

Doyle, L. H. (2003). Synthesis through meta-ethnography: Paradoxes, enhancements, and possibilities. Qualitative Research, 3, 321-344.

Duguid, P. (2005). "The art of knowing": Social and tacit dimensions of knowledge and the limits of the community of practice. The Information Society, 21, 109-118.

Durkheim, E. (1965 [1912]). The elementary forms of religious life. New York, NY: Free Press.

Felin, T., \& Foss, N. (2006). Individuals and organizations: Thoughts on a microfoundations project. In: D. J. Ketchen \& D. D. Burgh (Eds), Research methodology in strategy and management (Vol. 3, pp. 253-288). Oxford: Elsevier.

Floyd, S. W., \& Wooldridge, B. (1992). Middle management involvement in strategy and its association with strategic type: A research note. Strategic Management Journal, 13, 153-167.

Garfinkel, H. (1961). Studies in ethnomethodology. Oxford: Polity Press.

Gioia, D. A., Schultz, M., \& Corley, K. G. (2000). Organizational identity, image, and adaptive instability. Academy of Management Review, 25, 63-81.

Granovetter, M. (1985). Economic action and social structure: The problem of embeddedness. American Journal of Sociology, 91, 481-510.

Hammersley, M., \& Atkinson, P. (1995). Ethnography: Principles in practice (2nd ed.). London: Routledge.

Hannan, M. T., \& Freeman, J. (1989). Organizational ecology. Cambridge, MA: Harvard University Press.

Hannan, M. T., Polos, L., \& Carroll, G. R. (2007). Logics of organization theory: Audiences, codes, and ecologies. Princeton, NJ: Princeton University Press.

Hatch, M. J., \& Schultz, M. (2002). The dynamics of organizational identity. Human Relations, 55, 989-1018.

Hodson, R. (2004a). A meta-analysis of workplace ethnographies: Race, gender, and employee attitudes and behaviors. Journal of Contemporary Ethnography, 33, 4-38.

Hodson, R. (2004b). Organizational trustworthiness: Findings from the population of organizational ethnographies. Organization Science, 15, 432-445.

Hsu, G. (2006). Jacks of all trades and masters of none: Audiences' reactions to spanning genres in feature film production. Administrative Science Quarterly, 51, 420-450.

Humphreys, M., \& Brown, A. D. (2002). Narratives of organizational identity and identification: A case study of hegemony and resistance. Organization Studies, 23, 421-447.

Jackall, R. (1988). Moral mazes: The world of corporate managers. New York, NY: Oxford University Press. 
Karreman, D., \& Alvesson, M. (2001). Making newsmakers: Conversational identity at work. Organization Studies, 22(1), 59-89.

King, B. G., Felin, T., \& Whetten, D. A. (2010). Finding the organization in organization theory: A meta-theory of the organization as a social actor. Organization Science, 21, 290-305.

King, B. G., \& Whetten, D. A. (2008). Rethinking the relationship between reputation and legitimacy: A social actor conceptualization. Corporate Reputation Review, 11, 192-207.

Knorr Cetina, K. (1999). Epistemic cultures: How the sciences make knowledge. London: Harvard University Press.

Latour, B. (2005). Reassembling the social: An introduction to actor-network-theory. Oxford: Oxford University Press.

Lynch, M. (1992). Extending Wittgenstein: The pivotal move from epistemology to the sociology of science. In: A. Pickering (Ed.), Science as practice and culture (pp. 215-265). London: University of Chicago Press.

McDonnell, E. M. (2011). The subcultural origins of bureaucracy. Doctoral thesis, Department of Sociology, Northwestern University, Evanston, IL.

Mead, G. H. (1934). Mind, self \& society from the standpoint of a social behaviorist. Chicago, IL: University of Chicago Press.

Merton, R. K. (1940). Bureaucratic structure and personality. Social Forces, 18, 560-568.

Meyer, J. W., \& Rowan, B. (1977). Institutionalized organizations: Formal structure as myth and ceremony. American Journal of Sociology, 83, 340-363.

Miles, M. B., \& Huberman, A. M. (1994). Qualitative data analysis (2nd ed.). Thousand Oaks, CA: Sage.

Noblit, G. W., \& Hare, R. D. (1988). Meta-ethnography: Synthesizing qualitative studies. London: Sage.

Orr, J. E. (1996). Talking about machines: An ethnography of a modern job. London: Cornell University Press.

Perrow, C. (1986). Complex organizations: A critical essay (3rd ed.). New York, NY: McGraw-Hill.

Pettit, P. (2003). Groups with minds of their own. In: F. Schmitt (Ed.), Socializing metaphysics: The nature of social reality (pp. 167-193). New York, NY: Rowan and Littlefield.

Phillips, D. J., \& Zuckerman, E. W. (2001). Middle-status conformity: Theoretical restatement and empirical demonstration in two markets. American Journal of Sociology, 107, 379-429.

Pratt, M. G., \& Kraatz, M. S. (2009). E pluribus unum: Multiple identities and the organizational self. In: L. M. Roberts \& J. E. Dutton (Eds.), Exploring positive identities and organizations (pp. 385-410). New York, NY: Routledge.

Prendergast, C. (1999). The provision of incentives in firms. Journal of Economic Literature, 37, $7-63$.

Schutz, A. (1962). Collected papers, volume one. The Hague: Nijhoff.

Scott, W. R. (2001). Institutions and organizations (2nd ed.). London: Sage.

Scott, W. R., \& Davis, G. F. (2007). Organizations and organizing: Rational, natural, and open system perspectives. Upper Saddle River, NJ: Pearson Prentice Hall.

Selznick, P. (1957). Leadership in administration. New York, NY: Harper \& Row.

Sillince, J. A. A., \& Brown, A. D. (2009). Multiple organizational identities and legitimacy: The rhetoric of police websites. Human Relations, 62, 1829-1856.

Simmel, G. (1971 [1908]). Group expansion and the development of individuality. In: D. N. Levine (Ed.), Georg Simmel: On individuality and social forms (pp. 251-293). Chicago, IL: University of Chicago Press. 
Star, S. L., \& Griesemer, J. R. (1989). Institutional ecology, 'translations' and boundary objects: Amateurs and professionals in Berkeley's Museum of Vertebrate Zoology, 1907-39. Social Studies of Science, 19, 387-420.

Swedberg, R., \& Agevall, O. (2005). The Max Weber dictionary: Key words and central concepts. Stanford, CA: Stanford Social Sciences.

Swidler, A. (1986). Culture in action: Symbols and strategies. American Sociological Review, 51, 273-286.

Thompson, J. D. (2008/[1967]). Organization in action: Social science bases of administrative theory. London: Transaction Publishers.

Tollefsen, D. (2002). Organizations as true believers. Journal of Social Philosophy, 33, 395-410.

Tripsas, M. (2009). Technology, identity, and inertia through the lens of 'the digital photography company'. Organization Science, 20(2), 441-460.

Tsoukas, H. (2005). Forms of knowledge and forms of life in organized contexts. In: H. Tsoukas (Ed.), Complex knowledge: Studies in organizational epistemology (pp. 6993). Oxford: Oxford University Press.

Weber, M. (1947). The theory of social and economic organization. Glencoe, IL: Free Press.

Weick, K. E. (2001). Organizational culture as a source for high reliability. In: K. E. Weick (Ed.), Making sense of the organization (pp. 330-344). Oxford: Blackwell.

Weick, K. E., \& Roberts, K. H. (1993). Collective mind in organizations: Heedful interrelating on flight decks. Administrative Science Quarterly, 38, 357-381.

Wenger, E. (1998). Communities of practice: Learning, meaning, and identity. New York, NY: Cambridge University Press.

Whetten, D. A. (2006). Albert and Whetten revisited: Strengthening the concept of organizational identity. Journal of Management Inquiry, 15, 219-234.

Whetten, D. A., \& Mackey, A. (2002). A social actor conception of organizational identity and its implications for the study of organizational reputation. Business \& Society, 41, 393-414.

Wrong, D. H. (1961). The oversocialized conception of man in modern sociology. American Sociological Review, 26/2, 183-193.

Ybema, S. (2010). Talk of change: Temporal contrasts and collective identities. Organization Studies, 31(4), 481-503.

Zuckerman, E. W. (1999). The categorical imperative: Securities analysts and the illegitimacy discount. American Journal of Sociology, 104, 1398-1438.

Zuckerman, E. W. (2004). Structural incoherence and stock market activity. American Sociological Review, 69, 405-432.

Zuckerman, E. W. (2010). Speaking with one voice: A "Stanford School" approach to organizational hierarchy. Research in the Sociology of Organizations, 28, 289-307. 